\title{
Unequivocal ICT in Enhancing the Essence of Democracy and Good Governance
}

\author{
Shoara Akter, Milon Molla, S. M. Robiul Islam \\ Islamic University, Kushtia, Bangladesh \\ Rezwanul Kabir, Faysul Alam \\ China University of Geosciences (Wuhan)
}

\begin{abstract}
It is true and sooth as far as Abraham Linkan's definition of democracy being implausible in a vast global democratic system. The definition of democracy of Abraham linkan is certainly palatable and practically realizable in those ancient times for states, then existed were smaller and nanoscopic and people could directly participate and realize the collective decisions (Abraham Linkan defamation—of the people, by the people, and for the people). In modern democracies, the Abraham Linkan's defamation was fast losing its relevance and people were groping in the dark. The citizens were challenging in the system on its essentials/prerequisites the state in modern times not only shirking its responsibility but also getting insulated. It was/is at this juncture the dawn of ICT on the horizon made people redeem nuances of participatory democracy development rhythm of true democratic ideals ICT's initiation in good governance heralded a new phase of participatory democracy development attended to the glorious of direct democracy. The emergency of the ICT filled the vacuum existed between govt. and citizens. It also narrowed down the gap between citizens and govt by holding out their responsibility in terms of development governance in veritably transparent manner. ICT, in other words, the net-work of information, are accessible to all decision-makers and also felicitated in decision-makers to have a direct access to the existing situation and there by strengthening the decision-making process. ICT by its inner strength restored the democratic strength to the citizenry. Thus, the main properties of ICT, such as transfrancy, participation, rule of low, efficiency and effectiveness, etc. propped up the governing entity get entrenched in good governance. Also, it opened new visas for creative discourse based on ICT's utility in the field of planning and designing of strategies of development at all levels of governing pyramid. The ICT's fold opportunities for both ruling and being ruled such that a citizenry could collectively constituency observe the action of ruling class as it is entailed to and in turn the government, in principal, has responsibility to focus on and positively respond to. Hence, ICT as a potential agency bridges the gap in all aspect of system yielding place for communion development. The role, ICT in a wider-democratic system and good governance, was also discussed. Conclusion is also drawn keeping in riew its futuristic perspectives and prospects.
\end{abstract}

Keywords: ICT, governance, felicitated, ruling class, communion development, wider-democratic system

Shoara Akter, M.S.S, Department of Public Administration, Islamic University, Kushtia, Bangladesh. Milon Molla, M.S.S, Department of Public Administration, Islamic University, Kushtia, Bangladesh. S. M. Robiul Islam, M.S.S, Department of Public Administration, Islamic University, Kushtia, Bangladesh. Rezwanul Kabir, M.S., Department of Public Administration, China University of Geosciences (Wuhan). Faysul Alam .Doctoral Fellow, Land Resources Management, China University of Geosciences(Wuhan). 


\section{Introduction}

With the rapid permeation of information and communication technologies (ICTs), new vistas and opportunities have been emerging and unfolding themselves for a revival of public discourse and improved governance efficiency. ICTs offer concrete credible and advantages opportunities for local and national governments to better their performance in respect of transparency, participation, and decentralization. Crest of ICTs within planning and design of development strategies helps to strengthen the establishment of efficient, effective, and transparent governance systems. On-line electronic deviled can vastly improve the catering of services and information flows from administrations to their constituencies; communication among administrations and citizens can be enhanced, and lastly, ICTs offer unique opportunities for commotions citizen involvement and participation in the decision-making process. This is particularly relevant in the context of developing countries, where many countries have recently underwent Tran's mortification of democratic setup and where despite of transformation, the men dispensation has been faced up with stiffing problem of lack of responsibility and transparency under over bearing corrupt practices.

\section{Issues Associated With Good Governance}

Good and bad governance requires the understanding of the kernel of the state which are embedded in the constitution and confronting the state. Governance means a process that is employed to achieve the noble dead of the state. Thus, governance simply implies the art of governing a people within a given territory or a state. Governance means a state in action. Governance in political sense is a more complex activity to achieve. Political governance is service centric. Thus, governance has a great deal to do with the allocation of values in the system, in this context. In this regard, the World Bank view governance as the manner, in which power is exercised in the management of a country's economic and social resources for development.

The World Bank fond out three key aspects of governance the form of a political regime; the process by which authority is exercised in the management of a country's social and economic resources and the capacity of governance to design, formulate, and implement policies and discharge functions. The United Nations Development Programme (1997) saw government and governance as being synonymous. Accordingly, it defined governance as a complex mechanisms, process, relationships, and institutions through which citizens and groups articulate their interests, exercise their legal rights, meet their obligations, and mediate their differences. Government, as an art of governance, enjoys four important attributes which include sovereignty, power, authority, and legitimacy. In these countries, the authors would like to different with Abadan as his statements lacks logical conclusion rather, they feel the ICT revolution will have both ends, such as citizens freedom and governments regulations met successful.

These attributes are the instruments of effective governance in the sense that they provide the necessary anchor and legal/moral justifications to the government. Governance includes institutional and structural arrangements, decision-making processes, policy formulation and implementation capacity, development of personnel, information flows, and the nature and style of leadership within a political system. By governance, we generally mean the manner, in which power is exercised by governments in the management and distribution of a country's social and economic resources. The manner of distribution makes governance a bad or good. Thus, when resources are distributed to promote inequality or to achieve personal or group clevises the essence of politics and state is defeated. Good governance, as a concept, is applicable to all sections of society, such as the government. 
What Organization for Economic Cooperation and Development (OECD) says good governance has eight major characteristics (UNESCO, 2005). They are participatory, consensus-oriented, accountable, transparent, responsive, effective and efficient, equitable and inclusive, and follow the rule of law. It assures that corruption is minimized; the voices of the most vulnerable in society are heard in decision-making. Failure of governance implies that political will has not properly managed the economy and social institutions. According to the World Bank (1992), bad governance has many features, such as failure to make a clear separation between public and what is private, hence a tendency to divert public resources for private gain; failure to establish a plausible framework for law and government behavior in a manner that is conducive to development, arbitrariness in the application of rules and laws; excessive rules, regulations, licensing requirements, etc, which impede the functioning of markets and encourage rent-seeking; and priorities that are inconsistent with development.

According to Obadan (1998), with features occurring together they create an environment that is hostile to development. He further argued Obedan that the authority of governments over their peoples tends to be progressively eroded. In authoritative regimes, coercion is wide-spread, equality in all respects degenerated, wealth being in consign nominal relations and also in those hands that are in proximity to power centre. Such regimes are usually characterized by abysmal decadence of human life, socio-economic and political life in such regimes are path entice democratic values are descry. Hence, such governance is bad governance. To undo this system by replenishing of democracies and e-governance to harness recourses in a manner that enriches socio-economic fabric of a political community, the resource utilized must also be commensurate with the level of development attained. In short, good governance is all about the performance capacity of a government and performance capabilities of leadership.

The best governing establishment or the governance is those that willingly or didactically respond to all round development of human kind in a given social system. That good governance extracts its citizens from the deep slumber where in, its citizens are groping for deliverance from wretched socio-economic detestable situations. In a sense, it arguments mantel, physical, and material prosperity of its denizens. Achieve the desired end of the state ends, such as equity, protection of life and property, enhanced participation, preservation of the rule of law, and improved living standard of the populace. The concept of "governance" is not new. It is as old as human civilization. Simply put "governance" means the process of decision-making and the process by which decisions are implemented (or not implemented). Governance loud is referred as corporate governance, international governance, national governance, and local governance.

Good governance has eight major characteristics. They are participatory, consensus-oriented, accountable, transparent, responsive, effective and efficient, equitable and inclusive, and follow the rule of law UNESCAP, 2012. It ensures that corruption is minimized the views of minorities and that the voices of the most vulnerable land considered are heard in decision-making.

\section{Characteristics of Good Governance}

1. Participation: Participation by both men and women is a key conrataisal essence of good governance. Participation could be either direct or through legitimate intermediate institutions or representatives. Representative democracy does not necessarily mean that the concerns of the most vulnerable shall be taken into consideration in decision-making. Participation needs to be informed and organized. This means freedom of association and expression on the one hand and an organized civil society on the other hand. 
2. Rule of law: Good governance prescribes for fair legal structural system that can be enforced impartially. It also assures full protection of human rights, particularly of those of minorities. Impartial enforcement of laws commends an independent judiciary and an impartial and incorruptible police force.

3. Transparency: Transparency means that decisions taken and their enforcement are done in a manner that follows rules and regulations. It also means that information is freely available and accessible to this affected by the decision and its enforcement. It also means that enough information is provided understandable forms of electronic media.

4. Responsiveness: Good governance stipulates all that institutions should serve all stakeholders within/under terms and condition laid down.

5. Consensus oriented: There are several actors and as many view points in a given society. Good governance requires mediation of the different interests in society to reach a broad consensus in society on what is in the best interest of the whole community and how this can be achieved. It also requires a broad and long-term perspective on what is needed for sustainable human development and how to achieve the goals of such development. This can only result from an understanding of the historical, cultural, and social contexts of a given society or community.

6. Equity and inclusiveness: A society's well being depends on ensuring that all its members feel that they have a stake in it and do not feel excluded from the mainstream. This includes all groups, especially the most vulnerable, and will have opportunities to improve themselves in all aspects of their existence.

7. Effectiveness and efficiency: Good governance means that processes and institutions produce results that meet the needs of society while making the best use of resources at their disposal. The concept of efficiency in the context of good governance covers the sustainable use of natural resources and the protection of the environment.

8. Accountability: Accountability is a key precondition of good governance. Not only of governmental institutions but also of the private sector and civil society organizations must be accountable to the public and to their institutional stakeholders. Who is accountable to whom varies depending upon whether decisions or actions taken are internal or external to an organization or institution. In general, an organization or an institution is accountable to those who will be affected by its decisions or actions. Accountability cannot be enforced without transparency and the rule of law.

\section{Essence of Democracy and E-democracy}

Democracy can be defined as, "Government by the people; especially, rule of the majority; a government in which the Supreme power is vested in the people and exercised by them directly or indirectly through a System of representation usually involving periodically held free elections (Merriam-Webster, 2012).

\section{E-democracy}

E-democracy is a term to mean invocation of wide range of responses and relations. E-democracy again would mean the appropriation of communication and information technologies and attend eat strategies within the conglomerated system of dispensations at all apparent levels of human life. This encases all that democratic, non-democratic, and the globe as such. The "democratic sectors" include the following democratic actors: governments, elected officials, media (and major online Portals), political parties and interest groups, civil society organizations, international governmental organizations, citizens/voters, etc. 


\section{E-governance}

There are the differences in as far as the representative institutions and elected officials use ICTs concerned administrative agencies and departments. The use of ICTs by parliaments, heads of state/government, and local lags far behind the administrative-based e-government service in matter fact is exploring their e-democracy responsibilities more Both parliamentarians and administration have to work parallels since both to achieve the goals of democracy and service. E-governance enhances the democratic development.

\section{ICT and Empowerment of Democracy}

ICTs in development and cooperation are with a view to promoting economic development and vast poverty reduction. ICTs have the potential to contribute to economic development and democratization and also democratic prerequisites and poverty reduction. Investment in traditional e-government service delivery is justified based on the provision of greater citizen convenience and the often-elusive goal of cost-savings. Another important aspect of it is that becoming more and more relevant today is the use of mobile technology for broadened participation of civil society in decision-making process, considered by governments and NGOs as a powerful means to engage citizens in political and social debates. According to the World Information Society Report 2007, jointly published by ITU and UNCTAD in May 2007, the number of mobile cellular subscribers around the world is growing rapidly. Thus, the number of mobile cellular subscribers rose from just 12 million in 1995 to over 1.15 billion in 2005. Low income countries are making important gains in mobile telephony with mobile phones outnumbering fixed lines by seven to one in least developed countries (LDCs), and by as much as nine to one in Sub-Saharan Africa. By the end of 2007, it is estimated that about half the world will have a mobile phone connection compared to about 300 million who have computers.

1. As a tool for bringing openness and effectiveness to local administration. its objects are uprooting corruption. This is crucial for countries like Nigeria, where corruption is still rampant. Efficient use of ICTs to fight corruption Kenya is the best example in the use Graft Management (EGM) project. The EGM project offered a corruption reporting facility in six towns with existing Internet infrastructure.

2. To increase the pace of service delivery that too, at a cheaper and most efficient and farther manner, the governance based on e-service shall be more advantages and hence gainful to the citizenry and precipitatively enable the citizen to option information and to carry out transactions 24 hours a day. Goals for e-government in governance that promote democracy and effective governance include:

1. Advanced government decisions;

2. Increased citizen credibility in government;

3. Enhancement of government accountability and transparency;

4. Ability to accommodate the public will in the information-age;

5. To effectively involve stakeholders, ranging from NGOs, business, and interested citizen in new Ways of handling public challenges.

\section{Challenges Before ICT for E-governance}

Many e-governance steps aiming to enhancing citizen participation and engagement have not fulfilled the promises offered by ICT technologies, and most of them have yet to spruce up towards improved information provision models of e-governance. This is mainly because of lack of institutional and legal e-readiness, and also of political will to fully exploit the potential offered by ICTs. Another important issue before ICT necessary 
infrastructure, creating conditions for capacity building and rising the level of knowhow and in defining a clear vision and strategic goals of e-governance and implementation. Lack of awareness among both the local population and policy-makers about the role ICTs play in enhancing good governance. The basic problem is that people simply do not see-in concrete, practical terms-how ICTs can make a difference to their lives, and how they can contribute to their development as individuals and as citizens of a country. People say away from knowing what ICT is all about its utility in the inclusive development.

\section{Prospective Consideration}

A potential solution, such as problems of connectivity and availability of technology could be to promote further implementation of Community Multimedia Centers (CMCs). CMCs offer affordable or free computer and internet access, training, and possibilities to connect with more remote communities using of wide-ranging e-technology. .

\section{Conclusion}

It could be gleaned from the above study that good governance is an ideal supreme and difficult to achieve in its totality. Only countries and societies have come about to a successful level in terms of achieving objectives in its totality. However, to ensure sustainable human development, actions must be initiated towards this ideal being a reality. Both government and public should officially involve themselves to transcolate the opportunities. With wisdom intelligent use of ICT and democratic intent, we can build better sustainable world. With the intelligent and effective application of ICTs, combined with democratic intent, we can make governments more responsive, we can connect citizens to effectively meet public challenges, and ultimately, we can build a more sustainable future for the benefit of the whole of society and world in which we live.

\section{References}

E-Governance and Public Net-Work. http://www.publicus.net. www.google.com

Madhav, G. (2007). Report of the one man committee on good governance. Retrieved from http://hrw.org/backgrounder/africa/nigeria0407/index/ht

Odunuga, S. (2003). Failure of governance and the phenomenon of conflict in Africa. In O. J Obi (Ed.), Philosophy, democracy and responsible governance in Africa (pp. 153-172). New Brunswick and London: Transaction Publishers.

UNESCO (2005). Good governance. Retrieved from http://portal.unesco.org/ci/en/ev.php-UNESCO

United Nations Development Programme (1997). Human development to eradicate poverty. Retrieved from http://hdr.undp.org/en/reports/global/hdr1997/

World Bank. (1992). Governance and development. Washington: International Bank for Reconstruction and Development.

Tokunbo Simbowale Osinubi. Does Stock Market Promote Economic Growth in Nigeria.

Department of Economics Faculty of the Social Sciences University of Ibadan, Ibadan Oyo State, Nigeria and Department of Economics Faculty of the Social Sciences University of Lagos, Akoka Yaba, Lagos State, Nigeria. 